\title{
EFFECT OF COMPOST, MINERAL NPK, EFFECTIVE MICROORGANISMS AND SOME VITAMIN TREATMENTS ON GROWTH, FRUIT YIELD AND ESSENTIAL OIL CONTENT OF CORIANDER (CORIANDRUM SATIVUM, L.) PLANTS
}

\author{
M.A.H. Abdou; A.A. El-Sayed; E.T. Ahmed and A.A.M. Abdel Salam \\ Hort. Dept., Fac. Agric., Minia Univ.
}

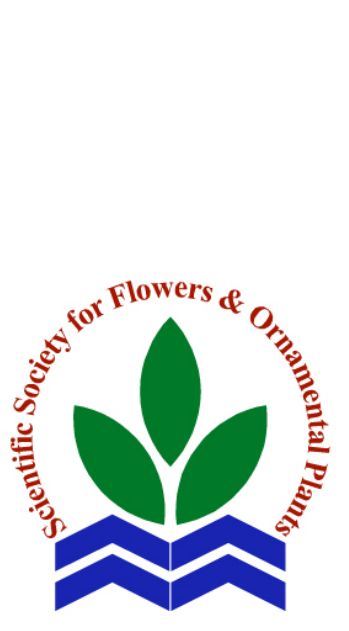

Scientific J. Flowers \& Ornamental Plants, 2(3):203-212 (2015).

Received:

29/9/2015

Revised by:

Prof. Dr. A.O. Gomaa, Banha Univ.

Prof. Dr. E.A.E. El-Ghadban, Hort. Res. Inst., ARC.

\begin{abstract}
Two field experiments were carried out during 2013/2014 and 2014/2015 seasons at the Experimental Farm, Fac. Agric., Minia Univ. to investigate the effect of compost $(0,5,7.5$ and 10 ton/fed), mineral NPK, effective microorganisms (E.M.), vit. E, vit. $\mathrm{B}_{1}$, E.M. + vit. E. and E.M. + vit. $\mathrm{B}_{1}$ on the growth and productivity
\end{abstract} (fruits and essential oil) of coriander plants.

The obtained data revealed that vegetative growth characters (plant height, stem diameter and herb dry weight/plant), yield components (number of umbels/plant, fruit yield/plant and /fed) and all studied oil production (oil \%, oil yield/plant and /fed) were significantly increased due to the application of all levels of compost over those of control treatments. The maximum values were recorded at the high level of compost (10 ton/fed). Vegetative growth characters, fruit yield and essential oil productivity parameters were significantly augmented as a result of using the different six treatments. The most effective treatments in this concern were mineral NPK (full dose) followed by E.M. + vit. E without significant difference between such superior treatments.

While, E.M. plus either vit. E or vit. $\mathrm{B}_{1}$ gave the highest essential oil \%. Moreover, E.M. + vit. E followed by NPK (full dose) recorded the highest essential oil yield/plant and /fed.

It could be recommended to supply Coriandrum sativum plants with compost at 10 ton/fed in combination with E.M. + vit. E. to alternative to compost (10 ton/fed) with mineral NPK (full dose) to ensure the safety, not only for human but also for the environment in which we live.

Key words: Coriandrum sativum, compost, E.M., NPK, vitamins, growth, essential oil.

\section{INTRODUCTION}

Coriander (Coriandrum sativum) belongs to the Apiaceae family. It is herbaceous annual plant, which is native to Mediterranean region. The coriander seeds have essential oil as an active substance, while linalool and pinene are the most important constituents of coriander which are used in pharmaceutical, food, perfumery and flavoring industry (Stary and Jirasck, 1975).

It is well known that the chemical fertilizers promote plant growth and productivity of medicinal and aromatic plants such as, Ayat (2007) and Rekaby (2013) on coriander, Al-Shareif (2006) and Abd El-Naeem (2008) on caraway. 
Organic material improve soil physical and chemical properties of soil that important for plant growth and improved the volatile oil in coriander (Osman, 2000; Khattab and Gomaa, 2004; Abdalla, 2009 and Rekaby, 2013) and khilla (Abdou et al., 2014) and black cumin (Ismail, 2008 and Shoor et al., 2010).

Effective microorganisms (E.M.) has been shown to be well for growth and able to increase the production of crops i.e. borage (Abdou et al., 2009); Calendula officinalis (Ali, 2013) and Ammi visnaga (Ibrahim, 2014).

Many authors concluded that some vitamins, as antioxidant materials had positive effects on the growth, yield and oil production such as Ramraj et al. (1997) on mustard, Refaat and Balbaa (2001) on lemongrass, Ismail (2008) on black cumin, Ayad et al. (2009) on geranium, Hendawy and Ezz El-Din (2010) on fennel, Abdou et al. (2013) on caraway and Abdou et al. (2014) on khilla.

Production of medicinal and aromatic plants using biofertilizers and natural substances became an essential process to ensure the safety, not only for human, but also for the environment in which we live. Therefore, it would be beneficial to use alternatives to chemical fertilizers. So, the present study was carried out to investigate the effect of compost, effective microorganisms and some antioxidants (vit.
$\mathrm{E}$ and vit. $\mathrm{B}_{1}$ ) on growth, fruit yield and oil production of coriander plants.

\section{MATERIALS AND METHODS}

Two field experiments were carried out during the two successive seasons of 2013/2014 and 2014/2015 at the Nursery and Laboratory, Fac. Agric. Minia Univ. Seeds of coriander plants were sown on September $20^{\text {th }}$ for both seasons, in $2.1 \times 2.1 \mathrm{~m}$ plots with $70 \mathrm{~cm}$ distance between the rows and $30 \mathrm{~cm}$ between hills within each raw. So, each plot contained 3 rows and 21 hills. Physical and chemical characters of the used soil are shown in Table (1).

Plants were thinned twice, the first one after one month from planting date and the second one after two weeks from the first one. All other agricultural practices were followed as usual.

A complete randomized block design following the split plot arrangement, in three replicates, was executed in this experiment with four compost treatments $(0,5,7.5$ and 10 ton/fed) in the main plots and six treatments [NPK, effective microorganisms (E.M.), alpha-tocopherol (vit. E), thiamine (vit. $\left.B_{1}\right)$, E.M. + vit. E and E.M. + vit. B $]$ in the sub plots. Compost amounts, for each treatment, were added to the soil during preparation. Physical and chemical properties of the compost are shown in Table (2).

The full dose of mineral NPK $(200 \mathrm{~kg}$

Table 1. Physical and chemical analysis of the experimental soil.

\begin{tabular}{|c|c|c|c|}
\hline Soil Character & Value & Soil Character & Value \\
\hline Sand \% & 28.30 & Available P \% & 15.12 \\
\hline Silt \% & 30.70 & Exch. $K^{+}$(mg/100 g soil) & 2.11 \\
\hline Clay \% & 41.00 & Exch. $\mathrm{Ca}^{++}(\mathrm{mg} / 100$ g soil $)$ & 31.74 \\
\hline Soil type & Clayey loam & Exch. $\mathrm{Na}^{+}(\mathrm{mg} / 100$ g soil $)$ & 2.41 \\
\hline Organic matter \% & 1.62 & \multirow{5}{*}{$\begin{array}{l}\text { DTPA } \\
\text { Ext. ppm }\end{array}$} & 8.54 \\
\hline $\mathrm{CaCO}_{3} \%$ & 2.09 & & 2.06 \\
\hline E.C. $(\mathbf{m m h o s} / \mathrm{cm})$ & 1.04 & & 2.75 \\
\hline pH $(1: 2.5)$ & 7.83 & & 8.26 \\
\hline Total N \% & 0.08 & & \\
\hline
\end{tabular}


Table 2. Physical and chemical properties of the used compost.

\begin{tabular}{lclc}
\hline Properties & Values & Properties & Values \\
\hline Dry weight of $\mathbf{1} \mathbf{~ m}^{\mathbf{3}}$ & $450 \mathrm{~kg}$ & $\mathbf{C} / \mathbf{N}$ ratio & $14.1-18.5$ \\
Fresh weight of $\mathbf{1} \mathbf{~ m}^{\mathbf{3}}$ & $650-700 \mathrm{~kg}$ & $\mathbf{N a C l} \%$ & $1.1-1.75$ \\
Moisture (\%) & $25-30$ & Total P \% & $0.5-0.75$ \\
pH (1:10) & $7.5-8$ & Total K \% & $0.8-1.0$ \\
E.C. $(\mathbf{m}$ mhose/cm) & $2-4$ & $\mathbf{F e ~ p p m ~}$ & $150-200$ \\
Total N \% & $1-1.4$ & $\mathbf{M n ~ p p m}$ & 25.56 \\
Org. matter \% & $32-34$ & $\mathbf{C u ~ p p m}$ & $75-150$ \\
Org. carbon \% & $18.5-19.7$ & $\mathbf{Z n ~ p p m}$ & $150-225$ \\
\hline
\end{tabular}

ammonium nitrate $+300 \mathrm{~kg}$ calcium superphosphate $+100 \mathrm{~kg}$ potassium sulphate /fed) was applied as follows : Total amounts of $\mathrm{P}$ fertilizer was added during preparing the soil to cultivation, while all amounts of NK were applied at three batches, after 45 days from planting date at one month intervals thereafter. E.M. was applied three times to the soil beside the plants at 50 $\mathrm{ml} /$ hill while, vit. E and vit. $\mathrm{B}_{1}$ were applied by hand sprayer three times. The first dose (for E.M., vit. E and vit. $\mathrm{B}_{1}$ ) was added after 53 days from planting date at one month thereafter.

At the end of experiment, the following data were recorded:

- Vegetative growth characters: Plant height $(\mathrm{cm})$, stem diameter $(\mathrm{mm})$ and herb dry weight/plant $(\mathrm{g})$.

- Yield and yield component parameters: number of umbels/plant, fruit yield/plant $(\mathrm{g})$ and fruit yield per fed $(\mathrm{kg})$.

- Essential oil determination: Essential oil $\%$, essential oil yield/plant $(\mathrm{ml})$ and $/$ fed (liter).

Statistical analysis: The obtained data were tabulated and statistically analyzed according to MSTAT-C (1986) and L.S.D. test at $5 \%$ was followed to compare between the means.

\section{RESULTS}

\section{1- Vegetative growth parameters:}

Data presented in Table (3) indicates that the three levels of compost had significantly a positive effect on vegetative growth characters i.e. plant height, stem diameter and herb dry weight/plant compared with the control. It is appeared that compost used at 10 ton/fed gave the maximum mean values of plant height (116.97 and $122.45 \mathrm{~cm})$, stem diameter (15.00 and $16.17 \mathrm{~mm})$ and herb dry weight/plant (55.23 and $55.72 \mathrm{~g}$ ) for both seasons, respectively. Obtained results agreed with those of Rekaby (2013) on coriander and Ibrahim (2014) on khilla plants. Also, the obtained results indicated that all used treatments of mineral NPK, effective microorganisms (E.M.) and/or vit. $\mathrm{E}$ or vit. $\mathrm{B}_{1}$ had remarkably positive effect on vegetative growth characters (plant height, stem diameter and herb dry weight/plant). The treatments of mineral NPK (full dose) followed by E.M. + vit. E. results the best values of vegetative growth traits comparing with other used treatments in both seasons (Table, 3). The roles of mineral NPK on plant growth were obtained by Abd El-Kader and Ghaly (2003), Ayat (2007) and Rekaby (2013) on coriander while biofertilizer as E.M. had positive effect on vegetative growth parameters as reported by Abdou et al. (2009) on borage, Ali (2013) on Calendula officinalis and Ibrahim (2014) on khilla plants. Also, vitamins as antioxidant increased plant growth characters as mentioned by Ramraj et al. (1997) on mustard, Ismail (2008) on black cumin and Abdou et al. (2013) on caraway.

The interaction between main and sub plots $(A \times B)$ was significant for plant height, stem diameter and herb dry weight/plant 
Table 3. Effect of compost, NPK, E.M. and some vitamins (vitamin E and vitamin $B_{1}$ ) on plant height $(\mathrm{cm})$, stem diameter $(\mathrm{mm})$ and herb dry weight/plant $(\mathrm{g})$ of coriander (Coriandrum sativum, L.) plants, during the first and second seasons.

\begin{tabular}{|c|c|c|c|c|c|c|c|c|c|c|}
\hline \multirow{3}{*}{$\begin{array}{l}\text { NPK, E.M. and some } \\
\text { vitamins (vitamin E } \\
\left.\text { and vitamin } B_{1}\right)(B)\end{array}$} & \multicolumn{10}{|c|}{ Compost levels (ton/fed) (A) } \\
\hline & \multicolumn{5}{|c|}{$1^{\text {st }}$ season $(2013 / 2014)$} & \multicolumn{5}{|c|}{$2^{\text {nd }}$ season $(2014 / 2015)$} \\
\hline & 0.0 & 5.0 & 7.5 & 10.0 & $\begin{array}{c}\text { Mean } \\
\text { (B) }\end{array}$ & $\mathbf{0 . 0}$ & 5.0 & 7.5 & 10.0 & $\begin{array}{c}\text { Mean } \\
\text { (B) }\end{array}$ \\
\hline \multicolumn{11}{|c|}{ Plant height (cm) } \\
\hline NPK & 107.1 & 112.5 & 118.4 & 123.2 & 115.30 & 112.5 & 118.1 & 124.0 & 129.0 & 120.90 \\
\hline E.M. & 101.1 & 106.2 & 111.9 & 116.4 & 108.90 & 106.1 & 111.5 & 117.1 & 121.8 & 114.13 \\
\hline Vitamin E & 98.2 & 103.1 & 108.4 & 112.7 & 105.60 & 103.2 & 108.4 & 113.8 & 118.4 & 110.95 \\
\hline Vitamin $B_{1}$ & 95.6 & 100.4 & 105.5 & 109.7 & 102.80 & 99.4 & 104.4 & 109.7 & 114.2 & 106.93 \\
\hline E.M. + Viamin E & 105.6 & 110.9 & 116.6 & 121.3 & 113.60 & 110.8 & 116.3 & 122.1 & 126.9 & 119.03 \\
\hline E.M. + Vitamin $B_{1}$ & 103.2 & 108.4 & 113.9 & 118.5 & 111.00 & 108.4 & 113.8 & 119.5 & 124.4 & 116.53 \\
\hline Mean (A) & 101.80 & 106.92 & 112.45 & 116.97 & & 106.73 & 112.08 & 117.70 & 122.45 & \\
\hline L.S.D. at $5 \%$ & \multicolumn{2}{|c|}{$\mathrm{A}=4.11$} & $\mathrm{~B}=3.71$ & \multicolumn{2}{|c|}{$\mathrm{AB}=7.42$} & \multicolumn{2}{|c|}{$\mathrm{A}=4.73$} & $\mathrm{~B}=3.55$ & \multicolumn{2}{|c|}{$\mathrm{AB}=7.10$} \\
\hline \multicolumn{11}{|c|}{ Stem diameter $(\mathrm{mm})$} \\
\hline NPK & 13.8 & 14.5 & 15.2 & 16.0 & 14.88 & 14.7 & 15.5 & 16.3 & 17.0 & 15.88 \\
\hline E.M. & 12.8 & 13.4 & 14.1 & 14.8 & 13.79 & 13.8 & 14.5 & 15.3 & 16.0 & 14.90 \\
\hline Vitamin E & 12.6 & 13.2 & 13.9 & 14.6 & 13.58 & 13.6 & 14.3 & 15.0 & 15.8 & 14.68 \\
\hline Vitamin $B_{1}$ & 12.3 & 12.9 & 13.5 & 14.2 & 13.23 & 13.4 & 14.1 & 14.7 & 15.5 & 14.43 \\
\hline E.M. + Viamin E & 13.2 & 13.8 & 14.5 & 15.3 & 14.20 & 14.2 & 14.9 & 15.7 & 16.5 & 15.33 \\
\hline E.M. + Vitamin $B_{1}$ & 13.0 & 13.6 & 14.3 & 15.1 & 14.00 & 14.0 & 14.8 & 15.4 & 16.2 & 15.10 \\
\hline Mean (A) & 12.95 & 13.57 & 14.25 & 15.00 & & 13.95 & 14.68 & 15.40 & 16.17 & \\
\hline L.S.D. at $5 \%$ & \multicolumn{2}{|c|}{$\mathrm{A}=0.52$} & $\mathrm{~B}=0.60$ & \multicolumn{2}{|c|}{$\mathrm{AB}=1.20$} & \multicolumn{2}{|c|}{$\mathrm{A}=0.75$} & $\mathrm{~B}=0.55$ & \multicolumn{2}{|c|}{$\mathrm{AB}=1.10$} \\
\hline \multicolumn{11}{|c|}{ herb dry weight/plant (g) } \\
\hline NPK & 36.9 & 44.2 & 52.1 & 60.1 & 48.33 & 42.3 & 49.9 & 57.3 & 65.8 & 53.83 \\
\hline E.M. & 33.9 & 40.6 & 48.0 & 55.2 & 44.43 & 36.2 & 42.4 & 48.9 & 56.3 & 45.95 \\
\hline Vitamin E & 32.6 & 39.2 & 46.2 & 53.1 & 42.78 & 34.2 & 40.4 & 46.4 & 53.0 & 43.50 \\
\hline Vitamin $B_{1}$ & 29.6 & 35.7 & 42.0 & 48.4 & 38.93 & 30.7 & 36.3 & 41.7 & 48.5 & 39.30 \\
\hline E.M. + Viamin E & 36.2 & 43.0 & 51.0 & 58.6 & 47.20 & 40.1 & 47.2 & 54.2 & 55.8 & 49.33 \\
\hline E.M. + Vitamin $B_{1}$ & 34.5 & 41.2 & 48.7 & 56.0 & 45.10 & 37.8 & 44.4 & 51.8 & 54.9 & 47.23 \\
\hline Mean (A) & 33.95 & 40.65 & 48.0 & 55.23 & & 36.88 & 43.43 & 50.05 & 55.72 & \\
\hline L.S.D. at $5 \%$ & \multicolumn{2}{|c|}{$\mathrm{A}=2.21$} & $\mathrm{~B}=2.40$ & \multicolumn{2}{|c|}{$\mathrm{AB}=4.80$} & \multicolumn{2}{|c|}{$\mathrm{A}=2.82$} & $\mathrm{~B}=2.90$ & \multicolumn{2}{|c|}{$\mathrm{AB}=5.80$} \\
\hline
\end{tabular}


(Table, 3). The highest values were obtained due to addition compost at 10 ton/fed in combination with mineral NPK (full dose) or E.M. + vit. E.

\section{2- Yield and yield components:}

Data presented in Table (4) revealed that compost, mineral NPK, E.M. and some vitamins and their interaction had significant positive effect in number of umbels/plant, fruit yield/plant and /fed. The three levels of compost $(5,7.5$ and 10 ton/fed) significantly increased number of umbels/plant, fruit yield per plant and per fed compared with control treatment. However, compost at 10 ton/fed resulted the highest increase of yield and yield components compared with control and other treatments.

Similar results were obtained by Osman (2000) and Abdalla (2009) on coriander and Abdou et al. (2014) on Ammi visnaga.

All six used treatments had significant effects on number of umbels/plant, fruit yield/plant and /fed (Table, 4). The lowest number of umbels (46.09 and 46.93) fruit yield per plant (23.03 and $24.61 \mathrm{~g}$ ) and fruit yield/fed (843 and $938 \mathrm{~kg}$ ) were obtained under thiamine (vit. $\mathrm{B}_{1}$ ), while the highest number of umbels/plant (49.18 and 53.56), fruit yield/fed (1230 and $1477 \mathrm{~kg})$ were obtained under mineral NPK (full dose) followed by the treatment of E.M. + vit. E which gave number of umbels (48.01 and 52.61), fruit yield/plant (30.28 and $35.68 \mathrm{~g}$ ) and fruit yield/fed (1154 and $1359 \mathrm{~kg}$ ) without significant differences between such two superior treatments. The other three treatments gave intermediate values.

These results are in agreement with those of Abd El-Kader and Ghaly (2003) on coriander, Abdou and Mohamed (2003) on fennel regarding the effects of mineral NPK. While, Abdou et al. (2009) on borage, Ali (2013) on Calendula officinalis and Ibrahim (2014) on Ammi visnaga concluded that E.M. biofertilizer had significantly increased yield of such plants. On the same time, similar findings were obtained by Hendawy and Ezz El-Din (2010) on fennel and Abdou et al. (2013) on caraway regarding the effects of some vitamins on yield and yield components.

The interaction treatments was significant for number of umbels/plant, fruit yield/plant and /fed in both seasons as indicated in Table (4).

The highest values were obtained with compost at high level (10 ton/fed) in combination with mineral NPK (full dose) or with E.M. + vit. E.

\section{3- Essential oil productivity:}

Essential oil percentage, oil yield/plant and oil yield/fed respond were significantly with compost, mineral NPK, E.M. and/or vit. $\mathrm{E}$ or vit. $\mathrm{B}_{1}$ treatments. Also, interaction between treatments had significant effects on this traits. The highest oil percentages $(0.37 \%$ and $0.40 \%$ in the first and second seasons, respectively), oil yield/plant (0.143 and $0.177 \mathrm{ml}$ in both seasons, respectively) and oil yield/fed (5.728 and 7.072 liter in both seasons, respectively) Table (5) were obtained at 10 ton/fed compost. Similar results were obtained by Osman (2000), Khattab and Gomaa (2004), Abdalla (2009) and Rekaby (2013) on coriander plants.

Mean comparison for mineral NPK (full dose), effective microorganisms and/or vit. $\mathrm{E}$ and vit. $\mathrm{B}_{1}$ showed that E.M. plus either vit. $\mathrm{E}$ or vit. $\mathrm{B}_{1}$ gave the highest oil $\%$ while, E.M. + vit. E followed by mineral NPK (full dose) then E.M. + vit. $B_{1}$ had the highest essential oil yield/plant and /fed (Table, 5).

Chemical fertilizers promote the essential oil production of coriander (Abd El-Kader and Ghaly, 2003, Ayat, 2007 and Rekaby, 2013). Biofertilizer able to increase the production of crops i.e. Hellal et al. (2011) on dill and Zand et al. (2013) on anise while, many authors found that some vitamins had positive effects on oil yield such as Refaat and Balbaa (2001) on lemongrass, Hendawy and Ezz El-Din (2010) on fennel. 
Table 4. Effect of compost, NPK, E.M. and some vitamins (vitamin E and vitamin $B_{1}$ ) on number of umbels/plant, fruits yield /plant (g/plant) and fruits yield/fed (ton/fed) of coriander (Coriandrum sativum, L.) plants, during the first and second seasons.

\begin{tabular}{|c|c|c|c|c|c|c|c|c|c|c|}
\hline \multirow{3}{*}{$\begin{array}{l}\text { NPK, E.M. and some } \\
\text { vitamins (vitamin } E \\
\left.\text { and vitamin } B_{1}\right)(B)\end{array}$} & \multicolumn{10}{|c|}{ Compost levels (ton/fed) (A) } \\
\hline & \multicolumn{5}{|c|}{$1^{\text {st }} \operatorname{season}(2013 / 2014)$} & \multicolumn{5}{|c|}{$2^{\text {nd }}$ season $(2014 / 2015)$} \\
\hline & 0.0 & 5.0 & 7.5 & 10.0 & $\begin{array}{c}\text { Mean } \\
\text { (B) }\end{array}$ & 0.0 & 5.0 & 7.5 & 10.0 & $\begin{array}{c}\text { Mean } \\
\text { (B) }\end{array}$ \\
\hline \multicolumn{11}{|c|}{ Number of umbels/plant } \\
\hline NPK & 36.48 & 39.76 & 43.34 & 46.87 & 41.62 & 37.93 & 41.34 & 45.07 & 48.67 & 43.25 \\
\hline E.M. & 33.10 & 36.08 & 39.22 & 42.47 & 37.72 & 34.45 & 37.55 & 40.98 & 44.21 & 39.30 \\
\hline Vitamin E & 31.18 & 33.99 & 37.05 & 40.01 & 35.56 & 32.17 & 35.07 & 38.29 & 41.18 & 36.68 \\
\hline Vitamin $B_{1}$ & 29.68 & 32.35 & 35.26 & 38.08 & 33.84 & 30.36 & 33.09 & 36.18 & 38.96 & 34.65 \\
\hline E.M. + Viamin E & 36.11 & 39.22 & 42.56 & 46.23 & 41.03 & 37.21 & 40.56 & 44.22 & 47.75 & 42.44 \\
\hline E.M. + Vitamin B & 34.06 & 37.13 & 40.17 & 43.51 & 38.72 & 35.95 & 39.19 & 42.73 & 46.13 & 41.00 \\
\hline Mean (A) & 33.44 & 36.42 & 39.60 & 42.86 & & 34.68 & 37.86 & 41.25 & 44.48 & \\
\hline L.S.D. at $5 \%$ & \multicolumn{2}{|c|}{$\mathrm{A}=2.19$} & $\mathrm{~B}=2.01$ & \multicolumn{2}{|c|}{$\mathrm{AB}=4.02$} & \multicolumn{2}{|c|}{$\mathrm{A}=2.55$} & $\mathrm{~B}=2.22$ & \multicolumn{2}{|c|}{$\mathrm{AB}=4.44$} \\
\hline \multicolumn{11}{|c|}{ Fruits yield /plant (g/plant) } \\
\hline NPK & 19.58 & 26.68 & 36.08 & 46.78 & 32.28 & 23.55 & 34.77 & 42.57 & 54.15 & 38.76 \\
\hline E.M. & 16.26 & 22.17 & 29.89 & 36.69 & 26.25 & 18.55 & 25.29 & 34.24 & 41.83 & 29.98 \\
\hline Vitamin E & 15.11 & 20.62 & 21.85 & 34.52 & 23.03 & 17.01 & 23.18 & 31.42 & 38.32 & 27.48 \\
\hline Vitamin $B_{1}$ & 13.69 & 18.67 & 25.26 & 30.94 & 22.14 & 15.21 & 20.74 & 28.12 & 34.35 & 24.61 \\
\hline E.M. + Viamin E & 18.81 & 25.56 & 34.41 & 42.35 & 30.28 & 22.08 & 30.10 & 40.66 & 49.87 & 35.68 \\
\hline E.M. + Vitamin $B_{1}$ & 17.29 & 23.60 & 33.66 & 40.89 & 28.86 & 20.56 & 28.04 & 37.91 & 46.67 & 33.30 \\
\hline Mean (A) & 16.79 & 22.88 & 30.19 & 38.70 & & 19.49 & 27.02 & 35.82 & 44.20 & \\
\hline L.S.D. at $5 \%$ & \multicolumn{2}{|c|}{$\mathrm{A}=3.91$} & $\mathrm{~B}=3.43$ & \multicolumn{2}{|c|}{$\mathrm{AB}=6.68$} & \multicolumn{2}{|c|}{$A=3.67$} & $\mathrm{~B}=3.18$ & \multicolumn{2}{|c|}{$\mathrm{AB}=6.36$} \\
\hline \multicolumn{11}{|c|}{ Fruits yield /fed (ton/fed) } \\
\hline NPK & 0.746 & 1.016 & 1.374 & 1.782 & 1.230 & 0.897 & 1.325 & 1.622 & 2.063 & 1.477 \\
\hline E.M. & 0.619 & 0.845 & 1.139 & 1.398 & 1.000 & 0.707 & 0.963 & 1.304 & 1.594 & 1.142 \\
\hline Vitamin E & 0.576 & 0.786 & 0.832 & 1.315 & 0.877 & 0.648 & 0.883 & 1.197 & 1.460 & 1.047 \\
\hline Vitamin $B_{1}$ & 0.522 & 0.711 & 0.962 & 1.179 & 0.843 & 0.579 & 0.790 & 1.071 & 1.309 & 0.938 \\
\hline E.M. + Viamin E & 0.717 & 0.974 & 1.311 & 1.613 & 1.154 & 0.841 & 1.147 & 1.549 & 1.900 & 1.359 \\
\hline E.M. + Vitamin $B_{1}$ & 0.659 & 0.899 & 1.282 & 1.558 & 1.099 & 0.783 & 1.068 & 1.444 & 1.778 & 1.269 \\
\hline Mean (A) & 0.640 & 0.872 & 1.150 & 1.474 & & 0.742 & 1.029 & 1.365 & 1.684 & \\
\hline L.S.D. at $5 \%$ & \multicolumn{2}{|c|}{$A=0.225$} & $B=0.131$ & \multicolumn{2}{|c|}{$\mathrm{AB}=0.262$} & \multicolumn{2}{|c|}{$\mathrm{A}=0.236$} & $\mathrm{~B}=0.120$ & \multicolumn{2}{|c|}{$\mathrm{AB}=0.240$} \\
\hline
\end{tabular}


Table 5. Effect of compost, NPK, E.M. and some vitamins (vitamin $\mathbf{E}$ and vitamin $B_{1}$ ) on oil percentage, oil yield /plant $(\mathrm{ml})$ and oil yield /fed (liter) of coriander (Coriandrum sativum, L.) plants, during the first and second seasons.

\begin{tabular}{|c|c|c|c|c|c|c|c|c|c|c|}
\hline \multirow{3}{*}{$\begin{array}{l}\text { NPK, E.M. and some } \\
\text { vitamins (vitamin E } \\
\text { and vitamin B1) (B) }\end{array}$} & \multicolumn{10}{|c|}{ Compost levels (ton/fed) (A) } \\
\hline & \multicolumn{5}{|c|}{ 1st season $(2013 / 2014)$} & \multicolumn{5}{|c|}{ 2nd season $(2014 / 2015)$} \\
\hline & 0.0 & 5.0 & 7.5 & 10.0 & $\begin{array}{c}\text { Mean } \\
\text { (B) }\end{array}$ & 0.0 & 5.0 & 7.5 & 10.0 & $\begin{array}{c}\text { Mean } \\
\text { (B) }\end{array}$ \\
\hline \multicolumn{11}{|c|}{ Oil percentage } \\
\hline NPK & 0.28 & 0.30 & 0.32 & 0.35 & 0.31 & 0.29 & 0.31 & 0.34 & 0.37 & 0.33 \\
\hline E.M. & 0.27 & 0.29 & 0.31 & 0.34 & 0.30 & 0.27 & 0.31 & 0.32 & 0.35 & 0.31 \\
\hline Vitamin E & 0.29 & 0.31 & 0.34 & 0.37 & 0.33 & 0.33 & 0.34 & 0.40 & 0.41 & 0.37 \\
\hline Vitamin B1 & 0.29 & 0.31 & 0.33 & 0.36 & 0.32 & 0.31 & 0.33 & 0.37 & 0.38 & 0.35 \\
\hline E.M. + Viamin E & 0.30 & 0.33 & 0.36 & 0.39 & 0.35 & 0.32 & 0.37 & 0.41 & 0.44 & 0.38 \\
\hline E.M. + Vitamin B1 & 0.30 & 0.32 & 0.34 & 0.38 & 0.34 & 0.31 & 0.35 & 0.40 & 0.44 & 0.37 \\
\hline Mean (A) & 0.29 & 0.31 & 0.33 & 0.37 & & 0.31 & 0.34 & 0.37 & 0.40 & \\
\hline L.S.D. at $5 \%$ & \multicolumn{2}{|c|}{$\mathrm{A}=0.02$} & $\mathrm{~B}=0.01$ & \multicolumn{2}{|c|}{$\mathrm{AB}=0.02$} & \multicolumn{2}{|c|}{$\mathrm{A}=0.03$} & $\mathrm{~B}=0.01$ & \multicolumn{2}{|c|}{$\mathrm{AB}=0.02$} \\
\hline \multicolumn{11}{|c|}{ Oil yield/plant (ml) } \\
\hline NPK & 0.055 & 0.080 & 0.115 & 0.164 & 0.100 & 0.068 & 0.108 & 0.145 & 0.200 & 0.128 \\
\hline E.M. & 0.044 & 0.064 & 0.093 & 0.125 & 0.079 & 0.050 & 0.078 & 0.110 & 0.146 & 0.093 \\
\hline Vitamin E & 0.044 & 0.064 & 0.074 & 0.128 & 0.076 & 0.056 & 0.079 & 0.126 & 0.157 & 0.102 \\
\hline Vitamin B1 & 0.040 & 0.058 & 0.083 & 0.111 & 0.071 & 0.047 & 0.068 & 0.104 & 0.131 & 0.086 \\
\hline E.M. + Viamin E & 0.056 & 0.084 & 0.124 & 0.165 & 0.106 & 0.071 & 0.111 & 0.167 & 0.219 & 0.136 \\
\hline E.M. + Vitamin B1 & 0.052 & 0.076 & 0.114 & 0.155 & 0.098 & 0.064 & 0.098 & 0.152 & 0.205 & 0.123 \\
\hline Mean (A) & 0.049 & 0.071 & 0.100 & 0.143 & & 0.060 & 0.092 & 0.133 & 0.177 & \\
\hline L.S.D. at $5 \%$ & \multicolumn{2}{|c|}{$\mathrm{A}=0.021$} & $\mathrm{~B}=0.008$ & \multicolumn{2}{|c|}{$\mathrm{AB}=0.016$} & \multicolumn{2}{|c|}{$\mathrm{A}=0.028$} & $\mathrm{~B}=0.011$ & \multicolumn{2}{|c|}{$\mathrm{AB}=0.022$} \\
\hline \multicolumn{11}{|c|}{ Oil yield /fed (liter) } \\
\hline NPK & 2.193 & 3.202 & 4.618 & 6.549 & 4.003 & 2.732 & 4.311 & 5.790 & 8.014 & 5.116 \\
\hline E.M. & 1.756 & 2.572 & 3.706 & 4.990 & 3.150 & 2.003 & 3.136 & 4.383 & 5.856 & 3.718 \\
\hline Vitamin E & 1.753 & 2.557 & 2.972 & 5.109 & 3.040 & 2.245 & 3.152 & 5.027 & 6.284 & 4.067 \\
\hline Vitamin B1 & 1.588 & 2.315 & 3.334 & 4.455 & 2.834 & 1.886 & 2.738 & 4.162 & 5.221 & 3.445 \\
\hline E.M. + Viamin E & 2.257 & 3.374 & 4.955 & 6.607 & 4.239 & 2.826 & 4.455 & 6.668 & 8.777 & 5.423 \\
\hline E.M. + Vitamin B1 & 2.075 & 3.021 & 4.578 & 6.215 & 3.925 & 2.549 & 3.926 & 6.066 & 8.214 & 4.928 \\
\hline Mean (A) & 1.948 & 2.837 & 3.985 & 5.728 & & 2.417 & 3.675 & 5.301 & 7.072 & \\
\hline L.S.D. at $5 \%$ & \multicolumn{2}{|c|}{$A=0.311$} & $\mathrm{~B}=0.315$ & \multicolumn{2}{|c|}{$\mathrm{AB}=0.630$} & \multicolumn{2}{|c|}{$A=0.375$} & $\mathrm{~B}=0.322$ & \multicolumn{2}{|c|}{$\mathrm{AB}=0.644$} \\
\hline
\end{tabular}


The combination treatments between compost (10 ton/fed) and mineral NPK (full dose) or E.M. + vit. E gave the highest values in both seasons.

\section{DISCUSSION}

The obtained results indicated the favorable effect of compost on coriander plant growth and productivity. Organic fertilizer improves the soil texture. The structural improvement can encourage the plant to have a good root development by improving the aeration in the soil, which leads to a higher plant growth. Also, the obtained results indicated the favorable effect of compost on coriander plant productivity, this result might be due to the role of organic material for continues supply of nutrients, growth stimulants, disease suppressors and support biologically diverse and metabolically dynamic process during the plant growth plays an essential role in the biosynthesis of the organic substances (Weltzien, 1990 and Fliessbach et al., 2000).

Generally, NPK fertilizers were applied to promote growth in different ways. Nitrogen is responsible for vegetative growth plant above ground and rapid maturity, while, Phosphorus is essential for strong roots and greater resistance to diseases. Potassium protects plant from cold condition and preventing excessive water loss (David Ojo, 1998). While, potassium functions as an osmoticum, reacts synergistically with IAA and carbohydrates translocation, (Mengel and Kirkby, 1987).

Effect of effective microorganisms on plant growth and biological yield was due to increased nutrient uptake and phytohormones. Also, adding of E.M. as biofertilizer to vitamins improve plant growth and increased the fruit yield and oil yield, the combined treatment resulted in maximum improvement of growth and yield of coriander. This improvement may be due to the direct effect of microorganisms (fix nitrogen, release certain phytohormones of $\mathrm{GA}_{3}$ and IAA) or indirect through the antioxidant activity of vit. E, since they have synergistic effect on growth and productivity. In addition in catching or chelating the free radical which playing toxic role during the plant development (Rao et al., 2000).

\section{REFERENCES}

Abdalla, M.Y.A. (2009). Effect of organic, bio and mineral fertilization on growth, yield, oil productivity and chemical constituents of coriander plant. J. Agric. Sci. Mansoura Univ., 34(5):5195-5208.

Abd El-Kader, H.H. and Ghaly, N.G. (2003). Effect of cutting the herb and the use of nitrobein and phosphorein associated with mineral fertilizers on growth, fruit and oil yield and chemical composition of essential oil of coriander plants (Coriandrum sativum, L.). J. Agric. Sci. Mansoura Univ. 28(3):2161 - 2171.

Abd El-Naeem, L.M.A. (2008). Response of Caraway Plants to Some Organic and Biofertilization Treatments. M.Sc. Thesis, Fac. Agric., Minia Univ., Egypt.

Abdou, M.A.H.; Aly, M.K.; Zaki, K.A.; Sadek, A.A. and El-Husseiny, R. (2009). Response of borage plants to some organic and biofertilization treatments. Proc. $5^{\text {th }}$ of Sustain, Agric. and Develop. Fac. Agric., Fayoum Univ. 21-23 December, p:143-158.

Abdou, H.A.H. and Mohamed, M.A. (2003). Growth and oil production of Foeniculum vulgare, Mill: 2. The effect of number of irrigations and fertilizers. J. Agric. Sci., Mansoura Univ., 28(5):4553-4563.

Abdou, M.A.H.; El-Sayed, A.A.; Taha, R.A. and Botros, W.S. (2013). Physiological studies on caraway plants. Proc. $1^{\text {st }}$ Inter of Hort. Agric. Assuit, February 2013.

Abdou, M.A.H.; Hamed, A.N.E.; El-Sayed, A.A.; Ahmed, E.T. and Ibrahim, T.I.E. (2014). Effect of some clean agricultural treatments on fruit yield, active ingredients and chemical composition of 
Ammi visnaga, L. Minia J. of Agric. Res. \& Develop. 34(1):1-12.

Ali, F.A.F. (2013). Effect of Organic and Biofertilization Treatments on Pot Marigold (Calendula officinalis, L.) Plants. M.Sc. Thesis, Fac. Agric., Minia Univ.

Al-Shareif, A.M.O. (2006). Response of Caraway Plants Grown in Sandy Soil Under Drip Irrigation System to Some Biofertilization and Antioxidant Treatments. M.Sc. Thesis., Fac. Agric., Minia Univ. Egypt.

Ayad, H.S.; Gamal El-Din, K.M. and Reda, F. (2009). Efficiency of stigmasterol and $\alpha$-tocophrerol application on vegetative growth, essential oil pattern, protein and lipid peroxidation of geranium (Pelargonium graveolens, L.). Journal of Applied Sci. Res., 5(7):887-892.

Ayat, A.M. (2007). Effect of Fertilization With Macro, Micro Nutrients and Antioxidants on Coriander (Coriandrum sativum, L.) Plants Grown in New Reclaimed Land. M.Sc. Thesis, Fac. Agric., Minia Univ. Egypt.

David Ojo, O. (1998). Growth and yield of Celosia argenata in response to a balanced NPK fertilizer. J. Vegetative Crop Prod., 4(1):77-83.

Fliessbach, A.; Mader, P.; Dubois, D. and Gunst, L. (2000). Results from 21 years old field trial. Organic farming enhances soil fertility and biodiversity. Bulletin Research of Organic Agriculture, 1:1519.

Hellal, F.A.; Mahfouz, S.A. and Hassan, F.A.S. (2011). Partial substitution of mineral nitrogen fertilizer by biofertilizer on Anethum graveolens, L. plant Agric. Biol. J. N. Am., 2(4):652-660.

Hendawy, S.F. and Ezz El-Din, A.A. (2010). Growth and yield of Foeniculum vulgare var. Azoricum as influenced by some vitamins and amino acids. Ozean Journal of Applied Sciences, 3(1):113-123.
Ibrahim, T.I.E. (2014). Influence of Some Agricultural Treatments on Ammi visnaga Plants. Ph.D. Thesis, Fac. Agric., Minia Univ., Egypt.

Ismail, S.I.I. (2008). Anatomical and Physiological Studies on Nigella sativa, L. Plant. Ph.D. Thesis, Fac. Agric., Mansoura Univ., Egypt.

Khattab, M.E. and Gomaa, A.M. (2004). Yield and essential oil quality of coriander as influenced by chicken manure, rock phosphate, sulfur and phosphate solubilizing Bacillus treatments. J. Agric. Sci., Mansoura Univ., 29(9):5231-5244.

Mengel, K. and Kirkby, A. (1987). Principles of Plant Nutrition, $4^{\text {th }}$ Ed. Inter Potash Institute, Bem, Switzerland.

MSTAT-C (1986). A Microcomputer Program for the Design, Management and Analysis of Agronomic Research Experiments (Version 4.0), Michigan Stat Univ., U.S.

Osman, Y.A. (2000). The Possibility of Production of Coriander (Coriandrum sativum, L.) Under Sinai Conditions. Ph.D. Thesis, Fac. Agric., Cairo Univ., Egypt.

Ramraj, V.M.; Vyas, B.N.; Godrej, N.B.; Mistry, K.B.; Swami, B.N. and Singh, N. (1997). Effect of 28-homobrassinolide on yields of wheat, rice, groundnut, mustard, potato and cotton. The J. Agric. Sci., 128:405-413.

Rao, M.V.; Koch, R. and Davis, K.R. (2000). Ozone a tool for probing programmed cell death in plants. Plant Mol. Biol., 44(3):346-358.

Refaat, Azza M. and Balbaa, L.K. (2001). Yield and quality of lemon grass plants (Cymbopogon flexuous stapf) in relation to foliar application of some vitamins and micro-elements. Egypt J. Hort. 28(1):4157.

Rekaby, A.M. (2013). Improving The Productively of Coriander Plants by The 


\section{M.A.H. Abdou et al.}

Use of Some Unconventional Treatments. Ph.D. Thesis, Fac. of Agric. Minia Univ.

Shoor, M.; Khalesi, N.; Kazemi, M.S. and Yazdi, K. (2010). Effect of organic manure and nitrogen fertilizer on yield, essence and extract of black cumin (Nigella sativa, L.). Abstract in the Proceeding of the International Medicinal and Aromatic Plants Symposium, June 21-23, Shiraz, Iran.

Stary, F. and Jirasck, V. (1975). A concise Guide in Color Herbs. Hamlin, London, New York, Sydney, Toronto.
Weltzien, H.C. (1990). The use of composted material for leaf disease suppression in field crop. Monograph of Organic Farming 45, 115-121.

Zand, A.; Darzi, M.T. and Hadi, M.R. (2013). Effects of phosphate solubilizing microorganisms and plant density of seed yield and essential oil content of anise (Pimpinella anisum). Middle East Journal of Scientific Research, 14(7):940-946.

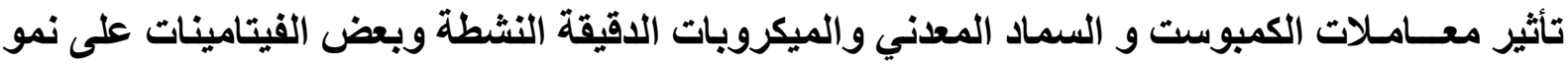

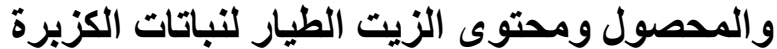 \\ محمود عبد الهادي حسن عبده، أحمد عبد المنعم السيد، عماد الدين توفيق الميار أحمد و أسماء أحمد محمد عبد السلام قسم البساتين، كلية الزر اعة، جامعة المنيا توفئ الحئ}

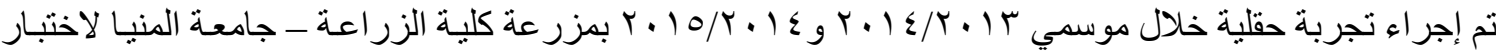

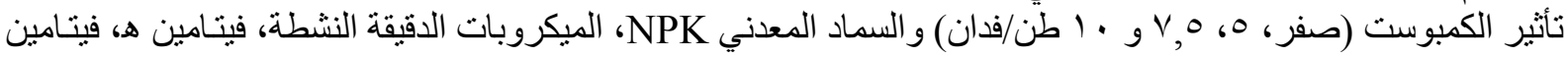

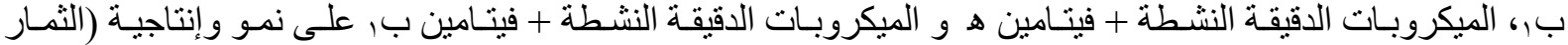

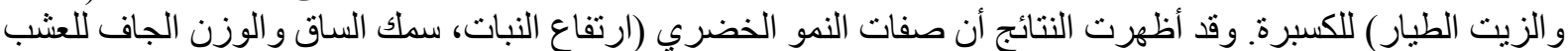

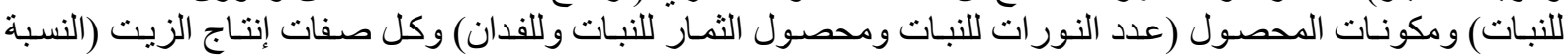

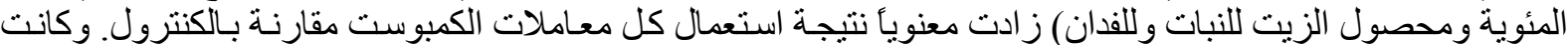

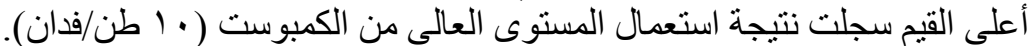

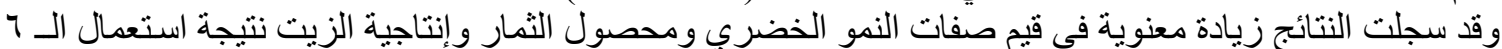
معاملات المختلفة وكانت أكثر ها كفاءة هي السماد المعدني NPK (جر عة كاملة) و الميكروبات الدئي الدقيقة النشطة + فيتامين هـ بدون فروق معنوية بينهما.

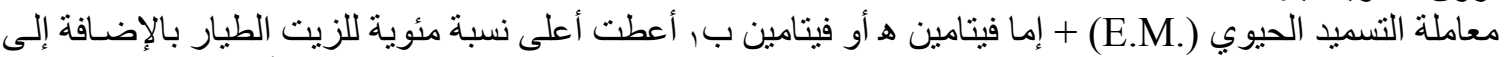

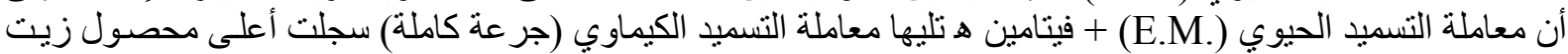
للنبات وللفدان.

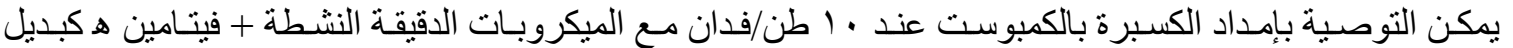
للكمبوست عند · ا طن/فذان مع السماد المعدني NPK (جر عـة كاملة) لتأكيد الأمسان لبس فقط للإنسـان ولكن أيضـاً للبيئة التي يعيش فيها الإنسان. 